\section{Pacific Northwest}

National Laboratory

Operated by Battelle for the

U.S. Department of Energy

\title{
On the Long-Term Average Cost of CO2 Transport and Storage
}

JJ Dooley

RT Dahowski

CL Davidson

March 2008

Prepared for the U.S. Department of Energy under Contract DE-AC05-76RL01830 


\title{
DISCLAIMER
}

This report was prepared as an account of work sponsored by an agency of the United States Government. Neither the United States Government nor any agency thereof, nor Battelle Memorial Institute, nor any of their employees, makes any warranty, express or implied, or assumes any legal liability or responsibility for the accuracy, completeness, or usefulness of any information, apparatus, product, or process disclosed, or represents that its use would not infringe privately owned rights. Reference herein to any specific commercial product, process, or service by trade name, trademark, manufacturer, or otherwise does not necessarily constitute or imply its endorsement, recommendation, or favoring by the United States Government or any agency thereof, or Battelle Memorial Institute. The views and opinions of authors expressed herein do not necessarily state or reflect those of the United States Government or any agency thereof.

\author{
PACIFIC NORTHWEST NATIONAL LABORATORY \\ operated by \\ BATTELLE \\ for the \\ UNITED STATES DEPARTMENT OF ENERGY \\ under Contract DE-AC05-76RL01830
}

Printed in the United States of America
Available to DOE and DOE contractors from the Office of Scientific and Technical Information,
P.O. Box 62, Oak Ridge, TN 37831-0062;
ph: (865) 576-8401
fax: $(865)$ 576-5728
email: reports@adonis.osti.gov

\begin{abstract}
Available to the public from the National Technical Information Service, U.S. Department of Commerce, 5285 Port Royal Rd., Springfield, VA 22161 ph: (800) 553-6847 fax: $(703) 605-6900$ email: orders@ntis.fedworld.gov online ordering: http://www.ntis.gov/ordering.htm
\end{abstract}

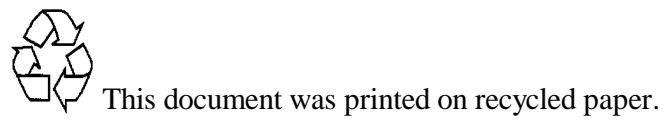




\section{On the Long-Term Average Cost of $\mathrm{CO} 2$ Transport and Storage}

JJ Dooley

RT Dahowski

CL Davidson

March 2008

Prepared for the U.S. Department of Energy under Contract DE-AC05-76RL01830

Pacific Northwest National Laboratory

Richland, Washington 99352 
ABSTRACT: This short paper extracts data from previously published research of ours to describe how the cost of pipeline-based $\mathrm{CO}_{2}$ transport and geologic storage varies across sitespecific circumstances likely to be encountered by a significant number of anthropogenic $\mathrm{CO}_{2}$ point sources. This paper disaggregates a $\$ 15 /$ tonCO $\mathrm{O}_{2}$ cost for transporting and storing $\mathrm{CO}_{2}$, which has been characterized in our work as a long-term average price.

KEY WORDS: carbon dioxide capture and storage; $\mathrm{CO}_{2}$ pipeline transport; $\mathrm{CO}_{2}$ storage in deep geologic formations; cost; carbon management; climate change.

SUGGESTED CITATION: JJ Dooley, RT Dahowski, CL Davidson. "'On the Long-Term Average Cost of $\mathrm{CO}_{2}$ Transport and Storage." Joint Global Change Research Institute. Pacific Northwest National Laboratory. February 2008. PNNL-17389. 
The U.S. Environmental Protection Agency (EPA) is currently using a cost of $\$ 15 /$ ton of $\mathrm{CO}_{2}$ $\left(\mathrm{tCO}_{2}\right)^{1}$ to represent the cost of transport and storage of $\mathrm{CO}_{2}$ once it has been captured from a large anthropogenic $\mathrm{CO}_{2}$ point source such as a power plant. This is being used within EPA's macroeconomic modeling of the cost of complying with various proposed $\mathrm{CO}_{2}$ emissions policies. This $\$ 15 / \mathrm{tCO}_{2}$ cost is based upon previously published research of ours and we have been asked to shed some light on the relative contribution of the cost of $\mathrm{CO}_{2}$ transport and the cost of $\mathrm{CO}_{2}$ storage (including measurement, monitoring and verification) to this overall $\$ 15 / \mathrm{tCO}_{2}$ figure. $^{2}$

This $\$ 15 /$ tonCO $\mathrm{CO}_{2}$ cost for storing $\mathrm{CO}_{2}$ is characterized in our work as a long-term average price that seems to describe the site-specific circumstances likely to be encountered by a significant number of anthropogenic $\mathrm{CO}_{2}$ point sources. However, this represents neither the exact cost for a given power plant, nor the cost likely to be encountered by all anthropogenic $\mathrm{CO}_{2}$ sources. Despite the general statement that a significant fraction of CCS projects in the U.S. will fall in the $\$ 15 / \mathrm{tCO}_{2}$ range, the cost of deploying CCS systems will vary significantly from project to project, depending upon a host of source- and site-specific conditions.

Key contributors to the variability in estimated $\mathrm{CO}_{2}$ transport and storage costs include:

- The type and individual characteristics of the anthropogenic $\mathrm{CO}_{2}$ point source from which $\mathrm{CO}_{2}$ is being captured and in particular the expected $\mathrm{CO}_{2}$ flow rate (given the economies/diseconomies of scale associated with transport and storage);

- Transport distance and terrain that a $\mathrm{CO}_{2}$ pipeline must traverse between the source and selected storage reservoir;

- Characteristics of the selected storage reservoir (e.g., reservoir type, depth, permeability, net thickness, pressure, etc.)

It is the specific combination of these factors for each individual source/reservoir pair that will determine the transport and storage costs and contribution of each to the total estimated combined cost. Because of the degree of variability of these parameters from one potential project to the next, the cost of deploying CCS systems will likely continue to span a wide range. Still, this $\$ 15 /$ tonCO $\mathrm{CO}_{2}$ cost assumption is a useful, robust and appropriately conservative proxy for transport and storage costs likely to be encountered across a significant fraction of potential future commercial CCS deployment scenarios, which EPA can apply in its modeling without having to model tens of thousands of potential site-specific cases.

The following chart illustrates the actual modeled cost split for 6 sample points on this part of the $\mathrm{CO}_{2}$ transport and storage cost curve, where the totals approximate $\$ 15 / \mathrm{tCO}_{2}$. These specific points were selected to represent the typical variation in component costs across the numerous source-reservoir pairings in this region of the cost curve. ${ }^{3}$ The accompanying table highlights

\footnotetext{
${ }^{1}$ All financial data presented in this paper are in 2005 U.S. dollars. " $\mathrm{tCO}_{2}$ " refers to metric tons of carbon dioxide.

${ }^{2}$ RT Dahowski, JJ Dooley, CL Davidson, S Bachu and N Gupta. Building the Cost Curves for $\mathrm{CO}_{2}$ Storage: North America. Technical Report 2005/3. International Energy Agency Greenhouse Gas R\&D Programme.

${ }^{3}$ As described in detail in Dahowski et. al. 2005, each of these six source-sink cost parings were extracted from a larger integrated analysis of the cost of employing CCS across the United States and Canada which employed an overall cost-minimizing optimization process that specifically took into account reservoir filling and the competition for storage space among sources as each large $\mathrm{CO}_{2}$ point source sought out its
} 
some of the key characteristics of the source-reservoir pairs which contribute to the transport and storage costs. As the figure shows, the fraction of each project's per-ton transport and injection cost attributed to either component varies significantly. For this reason, while we believe that this $\$ 15 / \mathrm{tCO}_{2}$ assumption is valid and useful for EPA's modeling purposes, it would be difficult and misleading to try to quote a "representative" cost proportion for either transport or storage for CCS in the U.S.

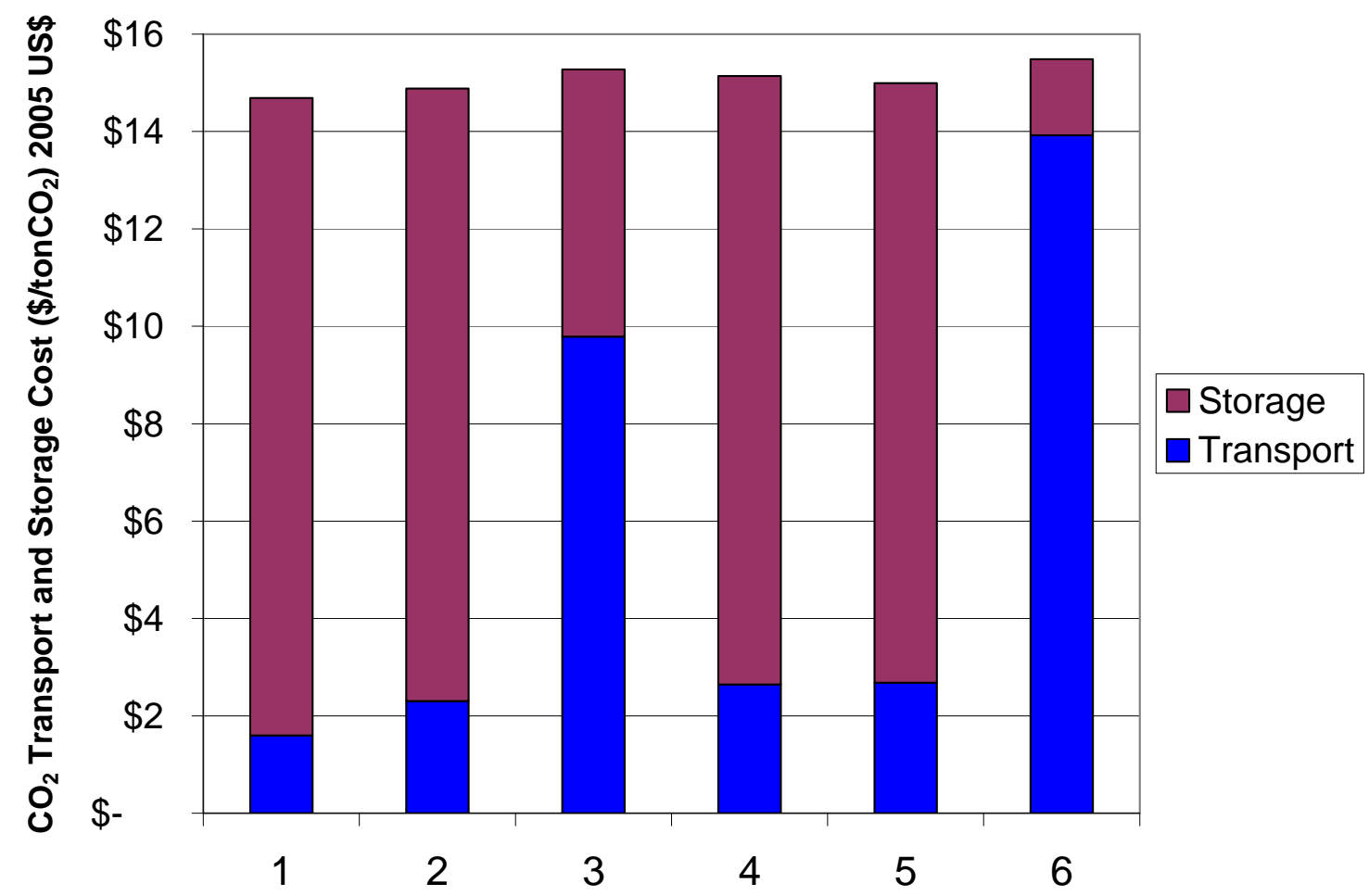

\begin{tabular}{|l|l|}
\hline Case & \\
\hline 1 & Oil refinery in Mississippi in the immediate vicinity of a depleted gas basin \\
\hline 2 & Small gas-fired power plant in Louisiana in the immediate vicinity of depleted gas basin \\
\hline 3 & Gas-fired power plant in New Mexico 60 miles away from unmineable coal seam \\
\hline 4 & Coal-fired power plant in Iowa 85 miles from a deep saline formation \\
\hline 5 & Coal-fired power plant in Wisconsin 50 miles from a deep saline formation \\
\hline 6 & Smaller cement kilns in Kansas in the immediate vicinity of a depleted oil field \\
\hline
\end{tabular}

Figure: Representative variation in transport and storage costs for projects with net transport/storage cost of about $\$ 15 / \mathrm{tCO}_{2}$, as illustrated by 6 sample points from the cost curve.

lowest cost storage option. The net result is that many large $\mathrm{CO}_{2}$ point sources with higher cost of capture (e.g., coal-fired power plants) might not be able to access their preferred storage option and must rely on $2^{\text {nd }}, 3^{\text {rd }}$ or other best options as cheaper sources of $\mathrm{CO}_{2}$ (e.g., a natural gas processing facility) out compete them for the storage space in the first best storage option. The impact of this on the U.S. electric power sector is addressed more fully in: Wise MA, JJ Dooley, RT Dahowski, and CL Davidson (2007).

"Modeling the impacts of climate policy on the deployment of carbon dioxide capture and geologic storage across electric power regions in the United States." International Journal of Greenhouse Gas Control.

Volume 1, Issue 2, April 2007, Pages 261-270. 